\title{
Antimicrobial Activity of Acidified Sodium Chlorite and Cell Free Culture Supernatent of Lactic Acid Bacteria against Salmonella Typhimurium
}

\author{
Sangeeta Singh ${ }^{1,2 *}$, Ajit Singh Yadav², Priyanka Bharti ${ }^{2}$ \\ ${ }^{1}$ Applied Science Department, Indian Institute of Information Technology, Allahabad, India \\ ${ }^{2}$ Food Microbiology Lab, Post Harvest Technology Division Central Avian Research Institute, Bareilly, India \\ Email: "sangeeta@iiita.ac.in, sony134@gmail.com
}

Received 19 October 2015; accepted 23 November 2015; published 26 November 2015

Copyright (C) 2015 by authors and Scientific Research Publishing Inc.

This work is licensed under the Creative Commons Attribution International License (CC BY). http://creativecommons.org/licenses/by/4.0/

(c) (i) Open Access

\begin{abstract}
Most methods used by food industries to decontaminate eggs involve washing of egg surface with various chemicals. In this study, the effectiveness of two organic decontaminants viz., acidified sodium chlorite (ASC) and cell free culture supernatant (CFCS) of two lactic acid bacteria (Lactobacillus plantarum and Pediococcus cerevisiae) was evaluated for the decontamination of spiked Salmonella Typhimurium on chicken egg shell surface. Acidified sodium chlorite at $100 \mu \mathrm{l} / \mathrm{L}$ concentration with the contact time of 20 min completely inhibited $S$. Typhimurium on egg shell surface while at $50 \mu \mathrm{l} / \mathrm{L}$ concentration $1-2 \log _{10}$ units reduction was observed in counts of $S$. Typhimurium as compared to control group. Likewise, CFCS of $P$. cerevisiae completely inhibited the growth of $S$. Typhimurium on 30 min contact, whereas $L$. plantarum and combination of both were revealed significant reduction in the counts of $S$. Typhimurium counts.
\end{abstract}

\section{Keywords}

Acidified Sodium Chlorite, Eggs, Lactobacillus plantarum and Pediococcus cerevisiae and Salmonella Typhimurium

\section{Introduction}

Eggs are highly nutritious and constitute an integral component of the human diet. They are also prone to con-

${ }^{*}$ Corresponding author.

How to cite this paper: Singh, S., Yadav, A.S. and Bharti, P. (2015) Antimicrobial Activity of Acidified Sodium Chlorite and Cell Free Culture Supernatent of Lactic Acid Bacteria against Salmonella Typhimurium. Journal of Biosciences and Medicines, 3, 128-135. http://dx.doi.org/10.4236/jbm.2015.311017 
tamination by various pathogenic microorganism viz. E. coli O157:H7, Campylobacter jejuni, Yersinia enterocolitica, etc. but among them Salmonella is the most predominant pathogen associated with it. Eggs and egg based products are the foods most frequently involved in Salmonella outbreaks and continue to be a significant public health problem. Although a wide range of Salmonella serovars can be isolated from eggs, S. Typhimurium and $S$. Enteritidis have been associated with most of the egg-borne outbreaks of salmonellosis [1]. Eggs get contaminated by Salmonella either from an infected hen (vertically) or during multiple steps along the food chain including processing, distribution, retail marketing and handling (horizontally) [2]. This calls for decontamination of Salmonella to reduce upward trend of incidence of egg-borne outbreaks and evolving appropriate methods or technology for the maintenance of egg quality during its movement from the farm to consumers.

Currently, most methods used by the food industry to decontaminate egg shell surfaces involve initially washing of them in detergent bath on conveyor rollers while being cleaned with brushes followed by treating them with various chemical solutions such as Lugol's solution, chlorihexadine, ethanol, and quartenary ammonium solutions. Exposure to ionized air, ozone in dry atmosphere, and pulsed UV-light has also been evaluated with varying degree of success [3] [4]. Even though, the agencies like Food Safety Inspection Service (FSIS), and Food Drug Administration (FDA) which are responsible for egg safety and the egg industries are investigating alternative decontamination techniques which could serve the public, minimize costs and benefit both the public and the industry [5].

Acidified sodium chlorite (ASC) has been approved by FDA for spray or dip application on various food products including poultry and poultry products, red meat, comminuted meat products, seafood and raw agricultural commodities [6]. ASC is highly effective broad spectrum antimicrobial produced by lowering the $\mathrm{pH}$ of a solution of sodium chlorite to 2.5 - 3.2 with any generally recognized safe acid. This combination results in the formation of the primary active component chlorous acid $\left(\mathrm{HClO}_{2}\right)$, which has strong antimicrobial properties primarily owing to its oxidative mode of action which is effective against bacteria, yeast, molds and viruses. A number of studies have described the strong efficacy of ASC on inactivation of pathogens like E. coli O157:H7 and Salmonella spp., [7] [8].

Lactic acid bacteria (LAB) are currently most investigated probiotic because they have received attention as a potential food preservative due to their strong antagonistic activity against many food-spoiling pathogenic organisms. Several lactic acid bactria such as Lactobacillus, Pediococcus, Bacteroides, Bifidobacterium, Enterococcus, and Helicobacter have been used as probiotics alone or in combination [9]-[12]. The antimicrobial activity of lactic acid bacteria against pathogenic microorganisms involves numerous mechanisms including the production of metabolites with an antimicrobial action like organic acids (lactic acid), hydrogen peroxide and specific proteins complexes called bacteriocins [13]-[16]. The anti-Salmonella Typhimurium activity of LAB strains has been investigated by previous researchers [17]. The objective of this study was to compare the efficacy of ASC at various concentrations and cell free culture supernatant of two LAB strains (Lactobacillus plantarum and Pediococcus cerevisiae) in reducing the counts of artificially inoculated S. Typhimurium on chicken egg shell surface.

\section{Materials and Methods}

\subsection{Bacterial Strains}

Salmonella Typhimurium (E-2391) was procured from National Salmonella Centre (Veterinary), Indian Veterinary Research Institute, Izatnagar, Bareilly. Lactobacillus plantarum (NCDC-231) and Pediococcus cerevisiae (NCDC-252) were procured from National Dairy Research Institute, Karnal. For revitalization, freeze-dried bacteria were subcultured in Brain Heart Infusion (BHI, Himedia Laboratories, Mumbai) and De Man Rogosa Sharpe (MRS, Difco Laboratories, USA) broth and incubated at $37^{\circ} \mathrm{C}$ for $24 \mathrm{~h}$. These strains were tested for their purity, morphological and biochemical characteristics and maintained by periodical subculturing on Nutrient agar (Himedia Laboratories, Mumbai) for S. Typhimurium and MRS agar (Difco Laboratories, USA) slants were used for Lactobacillus plantarum and Pediococcus cerevisiae.

\subsection{Inoculum}

Salmonella Typhimurium (E-2391) (Nalidixic acid resistant) was plated on Hektoen Enteric Agar (HEA, Himedia Laboratories, Mumbai). Single colony was transferred to $\mathrm{BHI}$ broth and incubated with agitation at $37^{\circ} \mathrm{C}$ for 
24 h. S. Typhimurium cells were harvested by centrifugation $(4000 \times \mathrm{g}, 15 \mathrm{~min})$ at $4^{\circ} \mathrm{C}$. Pelleted cells in centrifuge tube were washed with 2 volumes of sterile normal saline solution (NSS, $0.85 \% \mathrm{NaCl}$ ) and resuspended in it. The bacterial growth was quantified as per method of ICMSF [18] and the cell density adjusted approximately to $10^{6}$ cells/ml of bacterial suspension. Fresh inoculum was prepared for each experiment.

\subsection{Cell Free Culture Supernatant (CFCS) of Lactic Acid Bacteria}

Lactobacillus plantarum and Pediococcus cerevisiae were grown in MRS broth individually at $37^{\circ} \mathrm{C}$ for $24 \mathrm{~h}$ without shaking and CFCS from each culture was collected by centrifuging broth culture at $10,000 \times \mathrm{g}$ for 30 min at $4^{\circ} \mathrm{C}$. Centrifuged CFCS were passed through $0.22 \mu \mathrm{m}$ Millipore filter (Himedia Laboratories, Mumbai) and stored at $4^{\circ} \mathrm{C}$ till used. pH of CFCS was determined and found to be 4.2 to 4.5 .

\subsection{Acidified Sodium Chlorite (ASC)}

Sodium chlorite was acidified with citric acid following the manufacturer's (SRL, India) recommendations. Briefly, $1 \mathrm{~g}$ of citric acid and $0.8 \mathrm{~g}$ of sodium chlorite was dissolved in $10 \mathrm{ml}$ distilled water and kept at room temperature for 30 min before use (stock solution). Different concentration of ASC viz. $50 \mu \mathrm{l} / \mathrm{L}(\mathrm{pH}-3.0)$ and $100 \mu \mathrm{l} / \mathrm{L}(\mathrm{pH}-2.71)$ were prepared in distilled water from the stock solution.

\subsection{Inoculation of $S$. Typhimurium on Egg Shell Surface}

Chicken eggs were obtained from commercial poultry farm and cleaned by washing in tap water to remove residual matter present on its outer surface followed by immersed in $70 \%$ ethanol for 10 min to ensure that eggs were free from any contamination and held at room temperature for half an hour before experiment. An area of 2 $\times 1 \mathrm{~cm}^{2}$ on the surface of each egg was inoculated with $0.1 \mathrm{ml}$ of prepared inoculum of $S$. Typhimurium $\left(10^{6}\right.$ cells/ml) and kept under laminar flow for 15 min before treatment to facilitate the attachment of $S$. Typhimurium cells to its surface.

\subsection{Treatments of Inoculated Eggs with CFCS of Lactic Acid Bacteria and ASC}

Inoculated eggs were treated with CFCSs of Lactobacillus plantarum and Pediococcus cerevisiae individually and in combination of both through dipping for different contact time (10 min, 20 min and 30 min). Sterile distilled water and MRS broth were employed as control for this experiment. Similarly, varying concentration (50 $\mu \mathrm{l} / \mathrm{L}$ and $100 \mu \mathrm{l} / \mathrm{L}$ ) of ASC was sprayed on spiked egg shell surface for a number of time intervals (5 min, 10 min, $20 \mathrm{~min}$ and $30 \mathrm{~min}$ ) and sterile distilled water was used as control. Following exposure to above treatments, the marked area of egg shell was separated by cracking of egg, discarding the yolk and the white and crushed in sterile pestle-mortar containing $10 \mathrm{ml}$ of normal saline solution, from which 10 -fold serial dilution were prepared, plated on $\mathrm{HE}$ agar with $10 \%$ Nalidixic acid and incubated at $37^{\circ} \mathrm{C}$ for $24 \mathrm{~h}$ for enumeration of $S$. Typhimurium counts. Rappaport Vassiliadis (RV, Himedia Laboratories, Mumbai) and Tetrathionate (TT, Himedia Laboratories, Mumbai) broths were also inoculated from the NSS containing crushed egg shell and incubated at $37^{\circ} \mathrm{C}$ for $24 \mathrm{~h}$ for observing the growth of $S$. Typhimurium. Three trials were carried out for each experiment.

\subsection{Statistical Analysis}

Data obtained from above experiment was subjected to statistical analysis as per standard procedure of Snedecor and Cochran [19].

\section{Results and Discussion}

Acidified sodium chlorite was used for the decontamination of $S$. Typhimurium from egg shell surface. The mean log counts $\left(\log _{10}\right)$ for $S$. Typhimurium on egg shell surface between different treatment groups and contact periods are presented in (Table 1). Different concentrations of ASC were found to be effective in reducing $S$. Typhimurium counts and significant differences $(\mathrm{p}<0.05)$ were observed between treatment and control groups. Reduction in S. Typhimurium counts was directly proportional to concentration of ASC as well as contact time. Antimicrobial activity of ASC on spiked eggs was significantly influenced by the applied concentration with time. Thus, the reduction in S. Typhimurium counts increased with the increase in exposure time. Acidified 
Table 1. Effect of ASC on decontamination of artificially inoculated $S$. Typhimurium $\left(\log _{10} \mathrm{cfu} / \mathrm{cm}^{2}\right)$ on egg shell surface.

\begin{tabular}{cccccc}
\hline \multirow{2}{*}{ S. No. } & Contact time with & \multicolumn{3}{c}{ S. Typhimurium count $\left(\mathbf{l o g}_{\mathbf{1 0}} \mathbf{\mathbf { c f u } / \mathbf { c m } ^ { 2 } )}\right.$} & Overall mean \\
\cline { 3 - 5 } & ASC & Group I & Group II & Group III & \\
\hline 1 & $5 \mathrm{~min}$ & $3.71 \pm 0.31$ & $3.21 \pm 0.32$ & $3.25 \pm 0.34$ & $3.39^{\mathrm{a}} \pm 0.33$ \\
2 & $10 \mathrm{~min}$ & $3.52 \pm 0.34$ & $3.18 \pm 0.27$ & $3.16 \pm 0.34$ & $3.28^{\mathrm{a}} \pm 0.34$ \\
3 & $15 \mathrm{~min}$ & $3.46 \pm 0.29$ & $2.92 \pm 0.29$ & $2.29 \pm 0.27$ & $2.89^{\mathrm{b}} \pm 0.28$ \\
4 & $20 \mathrm{~min}$ & $3.27 \pm 0.27$ & $2.71 \pm 0.29$ & $00 \pm 0.29$ & $1.91^{\mathrm{C}} \pm 0.29$ \\
& Overall mean & $3.49^{\mathrm{A}} \pm 0.34$ & $3.00^{\mathrm{B}} \pm 0.29$ & $2.17^{\mathrm{C}} \pm 0.33$ & \\
\hline
\end{tabular}

Data are means \pm SE of ten determinants. Means with superscripts a, b, c in a column and A, B in a row differ significantly (p < 0.05). Group I: Untreated control, Group II: $50 \mu \mathrm{l} / \mathrm{L}$ ASC and Group III: $100 \mu \mathrm{l} / \mathrm{L}$ ASC.

sodium chlorite at $100 \mu \mathrm{l} / \mathrm{L}$ concentration with the contact time of 20 min completely inhibited S. Typhimurium on egg shell surface. Similar antimicrobial effect of ASC (0.1\%) against S. Typhimuirum on chicken skin has also been observed in an earlier study [20]. Other workers reported that ASC at $100 \mu \mathrm{l} / \mathrm{L}$ concentration effectively reduced the bacterial growth on food products [7] [8]. Ruiz-Cruz et al., (2007) reported that $100 \mu \mathrm{l} / \mathrm{L}$ was the optimum concentration of ASC for maintaining overall quality, firmness, inhibiting microbial growth and prolonging the shelf life of food products. While, ASC with the concentration of $50 \mu \mathrm{l} / \mathrm{L}$ indicated only reduction in $S$. Typhimurium counted instead of complete destruction. However, it reduced the counts by 1 - 2 log units as compared to control groups. Allende et al., [21] and Ruiz-Cruz et al., [8] also reported that lower concentration of ASC reduced the microbial population by 1 - $2 \log$ cfu/g in fresh-cut cilantro and shredded carrots when compared with control group samples which were closely corroborative to our study.

In addition, enrichment (RV and TT broth) step was also performed to recover bacteria injured during the treatment. This enrichment was applied to determine whether the different concentration of ASC was able to eliminate the $S$. Typhimurium or merely suppress their growth. Among ASC treated samples, no viable cells of $S$. Typhimurium were recovered at the concentration of $100 \mu \mathrm{l} / \mathrm{L}$ (20 min) indicating its bactericidal effect whereas ASC at lower concentrations had bacteriostatic effect on $S$. Typhimurium (Figure 1).

Conner (2001) and Caldwell et al. (2003) affirmed that ASC applied to inoculated fresh fruits and vegetables at $1.2 \mathrm{~g} / \mathrm{L}$ for $1 \mathrm{~min}$, killed at least 99.9\% of Salmonella serotypes, E. coli O157:H7, and L. monocytogenes on carrots, strawberries, tomatoes, cucumbers, lettuce, cantaloupe and apples. Gonzalez et al., (2004), Ruiz-Cruz et al., (2007) and Inatsu et al., (2005) [7] [8] [22] found a strong reduction in E. coli O157:H7, even under process water conditions, when using 0.5 and $1 \mathrm{~g} / \mathrm{L}$ ASC on shredded carrots and Chinese cabbage. Lukasik et al., 2003 [23] found that ASC at 0.1 and $0.2 \mathrm{~g} / \mathrm{L}$ was more effective in reducing E. coli O157:H7 and Salmonella Montevideo populations on strawberries than stabilized chlorine dioxide or free chlorine disinfectants at comparable concentrations.

ASC is recognized as highly potent, broad spectrum antimicrobial system that has been successfully developed for uses in veterinary, food processing and medical device fields. ASC chemistry is principally due to chlorous acid which is the metastable oxychlorine species that forms on acidification of chlorite. Once formed, chlorous acid gradually decomposes to form chlorate ion, chlorine dioxide and chloride ion. Its antimicrobial efficacy derives from the uncharged chlorous acid, which is able to penetrate bacterial cell walls and disrupt protein synthesis by virtue of its reaction with sulfhydry, sulfide and disulfide containing amino acids and nucleotides. The undissociated acid is thought to facilitate proton leakage into cells and thereby increase energy output of the cells to maintain their normal internal pH thereby also adversely affecting amino acid transport [24] [25].

Among Gram positive bacteria, lactic acid bacteria have been widely explored and considered to be a large reservoir of antimicrobial proteins that show a "natural effect" on food preservation [26]. Because of antimicrobial property possessed by lactic acid bacteria, cell free culture supernatant (CFCS) extracted from two different strains of lactic acid bacteria viz. Lactobacillus plantarum and Pediococcus cerevisiae individually and in combination were used in the present study for the decontamination of spiked $S$. Typhimurium on egg shell surface. Results indicated that CFCS of both the lactic acid bacterial strains on egg shell surface were found effective in reducing $S$. Typhimurium counts. Significant differences were observed between treatment groups as well as between varying contact periods of CFCS in reducing $S$. Typhimurium on egg shell surface. The mean 


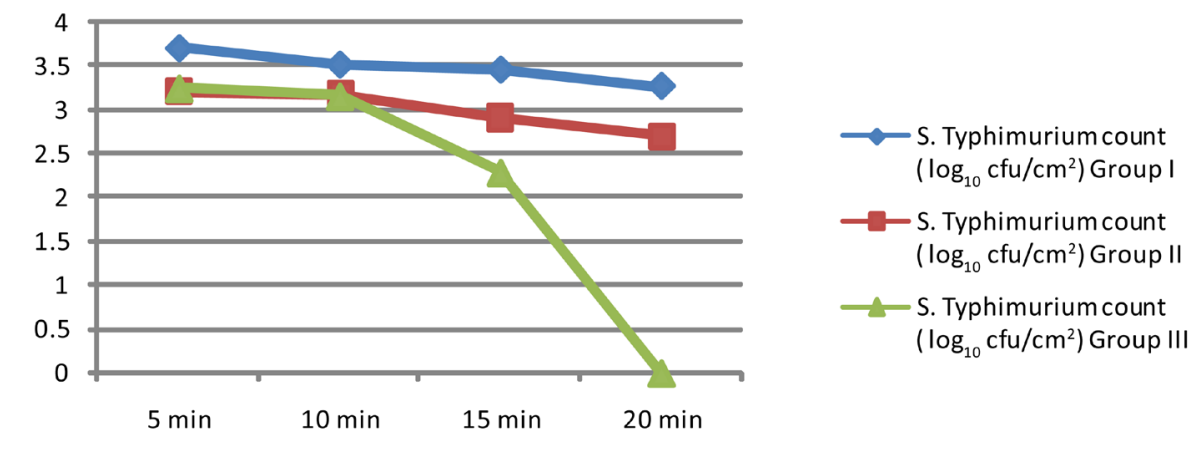

Figure 1. Salmonella Typhimurium count $\left(\log _{10} \mathrm{cfu} / \mathrm{cm}^{2}\right)$ on spiked egg shell surface treated with different concentration of ASC at various contact time.

logrithmic microbial counts $\left(\log _{10}\right)$ for spiked $S$. Typhimurium on egg shell surface between different treatment group and control group are shown in Table 2. The counts of $S$. Typhimurium were more or less remained the same after 10 min exposure in all the groups and no reduction was observed among different treatment and control groups but slight reduction was observed after exposure of spiked eggs with CFCS for 20 min.

Means bearing different small letter superscripts (a, b, c) in a column and capital letter superscripts (A, B) in a row differ significantly ( $\mathrm{p}<0.05$ ). LB: Lactobacillus plantarum extract, PD: Pediococcus cerevisiae extract, LB + PD: combination of Lactobacillus plantarum and Pediococcus cerevisiae extract \& MRS: Fresh MRS broth without lactic acid bacteria inoculation.

In the present study CFCS of $P$. cerevisiae was found to be more effective and indicated the complete inhibition of spiked $S$. Typhimurium $\left(10^{6} \mathrm{cfu} / \mathrm{ml}\right)$ on the egg shell surface with contact time of $30 \mathrm{~min}$. The complete inhibition of $S$. Typhimurium through $P$. cerevisiae may be due to the presence of pediocin (bacteriocin) or lower pH (4.5) effect exerted by its CFCS. Eijsink et al., 1998 [27] conducted comparative study on antimicrobial effect of class IIa bacteriocins of lactic acid bacteria and reported that pediocin has broader inhibitory spectrum and our results are in agreement with this study.

The destructive activity of $L$. plantarum was produced mainly by non-lactic acid molecules that were present in CFCS of the L. plantarum [28]. But Latobacillus plantarum CFCS were not completely inhibited the spiked S. Typhimurium on egg shell surface. However, they reduced the counts by $1-2 \log _{10}$ units as compared to control groups $(\mathrm{p}<0.05)$. Our results are in agreement with an earlier study where CFCS or bacteriocins produced by Lactobacillus were reported to have relatively narrow spectrum of antibacterial activity against important food borne pathogens like Listeria monocytogenes, Yersinia entericolitica, Campylobacter spp. and Salmonella spp. [9]. It has been previously reported that L. johnsonii [29], L. casi shirots [30], L. rhamnose [31] and L. acidophilus [32] exerts antagonistic activity against Gram-negative pathogens.

Combination of CFCS of both Lactobacillus plantarum and Pediococcus cerevisiae also revealed incomplete inhibition but higher reduction was observed in comparison to Lactobacillus plantarum CFCS. Lactobacillus plantarum CFCS revealed only $1 \log _{10}$ reduction while CFCS of both reduced the $S$. Typhimurium counts upto 2 $\log _{10}$ units as compared to control groups. The reason may be that the CFCS of Pediococcus cerevisiae complemented the antimicrobial activity of Lactobacillus plantarum CFCS by slightly lowering its $\mathrm{pH}$. Moreover, longer contact time (30 min) with CFCS of Lactobacillus plantarum and Pediococcus cerevisiae were found to reduce spiked $S$. Typhimurium counts on egg shell surface significantly as compared to shorter contact periods of 10 and 20 min indicating the longer time requirement for CFCS to exhibit their antimicrobial effect. Enrichment in RV and TT broth was also performed for the samples treated with CFCS of Lactobacillus plantarum and Pediococcus cerevisiae. From all the treated samples viable cells of $S$. Typhimurium was recovered indicating that effect of CFCS was only bacteristatic not bactericidal (Figure 2).

The antimicrobial activity of probiotic lactic acid strains is known to be multifactorial. The efficacy of the spectrum of action of lactic acid bacteria against pathogenic microorganisms is determined by the production of metabolites with an antimicrobial action, including organic acids such as lactic acid and acetic acid [13], hydrogen peroxide which inhibits the growth of pathogens based on a strong oxidant effect on bacterial cells [14] or molecular destruction of nucleic acid and cell proteins and the production of specific proteins or protein complexes called bacteriocins. The mechanism of the antimicrobial activity of probiotic lactic acid bacteria strains 
Table 2. Effect of extracts of lactic acid bacteria on decontamination of artificially inoculated $S$. Typhimurium (log 10 $\mathrm{cfu} / \mathrm{cm}^{2}$ ) on egg shell surface.

\begin{tabular}{cccccc}
\hline \multirow{2}{*}{ S. No. } & Treatment & \multicolumn{2}{c}{ S. Typhimurium count $\left(\mathbf{l o g}_{\mathbf{1 0}} \mathbf{~} \mathbf{f u} / \mathbf{c m}^{2}\right)$} & Overall mean \\
\cline { 3 - 5 } & & $\mathbf{1 0} \mathbf{~ m i n}$ & $\mathbf{2 0} \mathbf{~ m i n}$ & $\mathbf{3 0 ~} \mathbf{~ i n}$ & \\
\hline 1 & LB & $3.38 \pm 0.29$ & $3.2 \pm 0.27$ & $2.45 \pm 0.29$ & $3.19^{\mathrm{ab}} \pm 0.29$ \\
2 & PD & $3.34 \pm 0.28$ & $2.02 \pm 0.31$ & $00 \pm 0.28$ & $2.12^{\mathrm{c}} \pm 0.29$ \\
3 & LB+PD & $3.46 \pm 0.29$ & $2.77 \pm 0.29$ & $2.04 \pm 0.34$ & $2.76^{\mathrm{b}} \pm 0.30$ \\
4 & MRS & $3.42 \pm 0.29$ & $3.43 \pm 0.26$ & $3.48 \pm 0.29$ & $3.44^{\mathrm{a}} \pm 0.29$ \\
& Overall mean & $3.43^{\mathrm{A}} \pm 0.29$ & $3.22^{\mathrm{A}} \pm 0.28$ & $2.39^{\mathrm{B}} \pm 0.29$ & \\
\hline
\end{tabular}

Means bearing different small letter superscripts (a, b, c) in a column and capital letter superscripts (A, B) in a row differ significantly (p < 0.05). LB: Lactobacillus plantarum extract, PD: Pediococcus cerevisiae extract, LB + PD: combination of Lactobacillus plantarum and Pediococcus cerevisiae extract \& MRS: Fresh MRS broth without lactic acid bacteria inoculation.

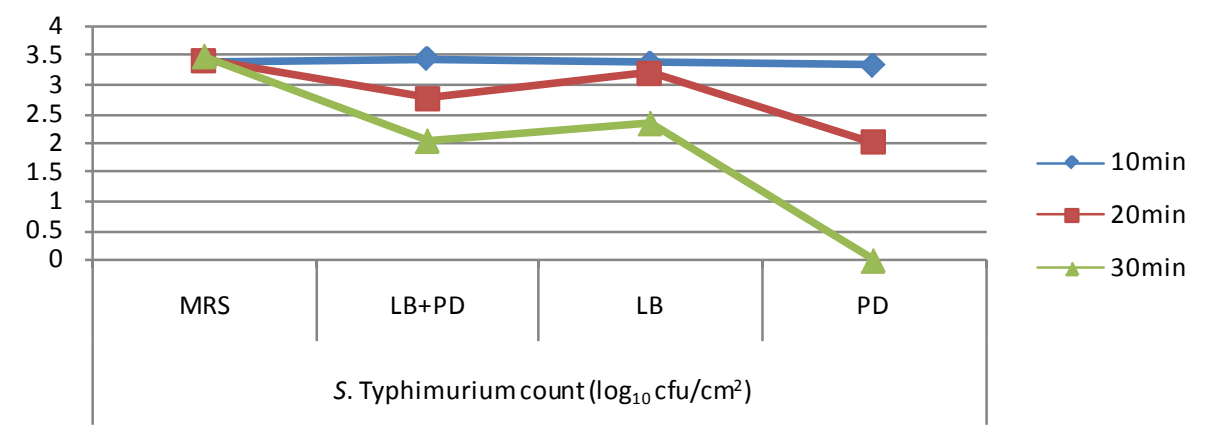

Figure 2. Salmonella Typhimurium count $\left(\log _{10} \mathrm{cfu} / \mathrm{cm}^{2}\right)$ on spiked egg shell surface treated with different extracts of lactic acid bacteria at various contact time. (LB: Lactobacillus plantarum extract, Pediococcus cerevisiae extract, LB + PD: combination of Lactobacillus plantarum and Pediococcus cerevisiae extract and MRS: Fresh MRS broth without lactic acid bacteria inoculation).

that leads to killing of bacterial pathogens may be due to synergistic action of lactic acid and non-lactic acid molecules [33].

\section{Acknowledgements}

The authors are thankful to the Director, Central Avian Research Institute, Izatnagar, India for providing necessary facilities.

\section{References}

[1] EFSA (2009) The Community Summary Report on Food-Borne Outbreaks in the European Union in 2007. EFSA Journal, 271, 1-102.

[2] Jones, F.T., Rive, D.V. and Carey, J.B. (1995) Salmonella Contamination in Commercial Eggs and an Egg Production Facility. Poultry Science, 74, 753-757. http://dx.doi.org/10.3382/ps.0740753

[3] Davies, R.H. and Breslin, M. (2003) Investigations into Possible Alternative Decontamination Methods for Salmonella Enteritidis on the Surface of Table Eggs. Jornal of Veterinary Medicine B, 50, 38-41. http://dx.doi.org/10.1046/j.1439-0450.2003.00622.x

[4] Hierro, E., Manzano, S., Ordonez, J.A., Hoz, L. and Fernandez, M. (2009) Inactivation of Salmonella Enterica Serovar Enteritidis on Shell Eggs by Pulsed Light Technology. International Journal of Food Microbioliology, 135, 125-130. http://dx.doi.org/10.1016/j.ijfoodmicro.2009.07.034

[5] CFSAN (2000) U.S. Egg Safety Action Plan. FDA, Rockville. http://www.cfsan.fda.gov/ dms/fs-eggs3.html

[6] Food and Drug Administration (FDA) (2000) Acidified Sodium Chlorite Solutions. Code of Federal Regulations, 21CFR173.325. http://www.accessdata.fda.gov/scripts/cdrh/cfdocs/cfcfr/CFRSearch.cfm 
[7] Gonzalez, R.J., Luo, Y., Ruiz-Cruz, S. and Mcevoy, J.L. (2004) Efficacy of Sanitizers to Inactivate Escherichia coli O157:H7 on Fresh-Cut Carrot Shreds under Simulated Process Water Conditions. Journal of Food Protection, 67, 2375-2380.

[8] Ruiz-Cruz, S., Acedo-Félix, E., Díaz-Cinco, M., Islas-Osuna, M.A. and González-Aguilar, G.A. (2007) Efficacy of Sanitizers in Reducing Escherichia coli O157:H7, Salmonella spp. and Listeria monocytogenes Populations on Fresh-Cut Carrots. Food Control, 18, 1383-1390. http://dx.doi.org/10.1016/j.foodcont.2006.09.008

[9] Nowroozi, J., Mirzaii, M. and Norauzi, M. (2004) Study of Lactobacillus as Probiotic Bacteria. Iranian Journal of Public Health, 33, 1-7.

[10] Lievin, V., Peiffer, I., Hudault, S., Rochat, F., Brassart, D., Neeser, J.R. and Servin, A.L. (2000) Bifidobacterium Strains from Resident Infant Human Gastrointestinal Microflora Exert Antimicrobial Activity. Gut, 47, 646-652. http://dx.doi.org/10.1136/gut.47.5.646

[11] Yoon, M.Y., Lee, K. and Yoon, S.S. (2014) Protective Role of Gut Commensal Microbes against Intestinal Infections. Journal of Microbiology, 52, 983-989. http://dx.doi.org/10.1007/s12275-014-4655-2

[12] Kim, J.E., Kim, M.S., Yoon, Y.S., Chung, M.J. and Yum, D.Y. (2014) Use of Selected Lactic Acid Bacteria in the Eradication of Helicobacter pylori Infection. Journal of Microbiology, 52, 955-962. http://dx.doi.org/10.1007/s12275-014-4355-y

[13] Gilliland, S.E. and Speck, M.L. (1972) Interactions of Food Starter Cultures and Food Borne Pathogens: Lactic Acid Streptococci versus Staphylococci and Salmonellae. Journal of Milk Food and Technology, 35, 307-310.

[14] Price, R.J. and Lee, J.S. (1970) Inhibition of Pseudomonas spp. by Hydrogen Peroxide Producing. Lactobacilli Milk and Food Technology, 33, 3-18.

[15] Servin, A.L. (2004) Antagonistic Activities of Lactobacilli and Bifidobacteria against Microbial Pathogens. FEMS Microbiology Review, 28, 405-440. http://dx.doi.org/10.1016/j.femsre.2004.01.003

[16] Reid, G., Jass, J., Sebulsky, M.T. and Mccormick, J.K. (2003) Potential Use of Probiotics in Clinical Practice. Clinical Microbiology Review, 16, 658-672. http://dx.doi.org/10.1128/CMR.16.4.658-672.2003

[17] Coconneir-Polter, M.H., Levin, V. and Servin, A.L. (2005) A Lactobacillus acidophilus Strain of Human Gastrointestinal Microbiota Origin Elicites Killing of Enterovirulent Salmonella enterica Serovar Typhimurium by Triggering Lethal Bacterial Membrane Damage. Applied Environmental Microbiology, 71, 6115-6120. http://dx.doi.org/10.1128/AEM.71.10.6115-6120.2005

[18] ICMSF (1978) International Commission for Microbiological Specialists for Food. Micro-Organism in Food-1, Their Significance and Methods of Enumeration. 2nd Edition, University of Toronto Press, Toronto, 115-118.

[19] Snedecor, G.W. and Cochran, W.G. (1980) Statistical Methods. 7th Edition, Oxford and IBH Publishing Co., Calcutta.

[20] Haydar, O. and Sebnem, P. (2006) Acidified Sodium Chlorite, Trisodium Phosphate and Populations of S. Typhimurium and Staphylococcus aureus on Chickens-Breast Skin. Journal of Food Processing and Preservation, 30, $237-247$.

[21] Allende, A., Mcevoy, J., Tao, Y. and Luo, Y. (2009) Antimicrobial Effect of Acidified Sodium Chlorite, Sodium Chlorite, Sodium Hypochlorite, and Citric Acid on Escherichia coli O157:H7 and Natural Microflora of Fresh-Cut Cilantro. Food Control, 20, 230-234. http://dx.doi.org/10.1016/j.foodcont.2008.05.009

[22] Inatsu, Y., Bari, M.L., Kawasaki, S., Isshiki, K. and Kawamoto, S. (2005) Efficacy of Acidified Sodium Chlorite Treatments in Reducing Escherichia coli O157:H7 on Chinese Cabbage. Journal of Food Protection, 68, 251-255.

[23] Lukasik, J., Bradley, M.L., Scott, T.M., Dea, M., Koo, A., Hsu, W.Y., et al. (2003) Reduction of Poliovirus 1, Bacteriophages, Salmonella Montevideo, and Escherichia coli O157:H7 on Strawberries by Physical and Disinfectant Washes. Journal of Food Protection, 66, 188-193.

[24] Warf, C.C. (2001) The Chemistry and Mode of Action of Acidified Sodium Chlorite. 2001 IFT Annual Meeting, New Orleans, 23-27 June 2001, 1-91.

[25] Martin, R.W. (2012) Method and Composition for In-Situ Generation of Chlorous Acid. US Patent No. 20120107418.

[26] Cleveland, J., Montville, J.J., Nes, I.F. and Chikindas, M. (2001) Bacteriocins: Safe, Natural Antimicrobials for Food Preservation. International Journal of Food Microbiology, 71, 1-20. http://dx.doi.org/10.1016/S0168-1605(01)00560-8

[27] Eijsink, V.G.H., Skeie, M., Middelhoven, P.N., Brurberg, B.M. and Nes, F.I. (1998) Comparative Studies of Class IIa Bacteriocins of Lactic Acid Bacteria. Applied Environmental Microbiology, 64, 3275-3281.

[28] Fayol-Messaoudi, D., Coconnier-Polter, M.H., Lievin, L.E., Moal, V., Atasi, F., Berger, C.N. and Servin, A.L. (2007) The L. plantarum Strain ACA-DC28 Isolated from a Greek Cheese Demonstrates Antagonistic Activity in Vitro and in Vivo against Salmonella enterica Serovar Typhimurium. Journal of Applied Microbiology, 103, 647-655. http://dx.doi.org/10.1111/j.1365-2672.2007.03293.x

[29] Tuomola, E.M., Ouwchand, A.C. and Salminen, S.J. (1999) The Effect of Probiotic Bacteria on the Adhesion of Pathogens to Human Intestinal Mucosa. FEMS Immunology and Medical Microbiology, 26, 137-142. 
http://dx.doi.org/10.1111/j.1574-695X.1999.tb01381.x

[30] Lee, Y.K., Puong, K.Y., Ouwehand, A.C. and Salminen, S. (2003) Displacement of Bacterial Pathogens from Mucus and Cacor 2 Cells Surface by Lactobacilli. Journal of Medical Microbiology, 52, 925-930. http://dx.doi.org/10.1099/jmm.0.05009-0

[31] Mcgroarty, J.A. and Reid, G. (1998) Detection of Lactobacillus Substances That Inhibits E. coli. Canadian Journal of Microbiology, 34, 974-978. http://dx.doi.org/10.1139/m88-171

[32] Chen, X., Xu, J., Shuai, J., Che, J., Zhang, Z. and Fang, W. (2007) The S-Layer Proteins of Lactobacillus crispatus Strain ZT001 Is Responsible for Competitive Exclusion against E. coli O157:H7 and S. Typhimurium. International Journal of Food Microbiology, 115, 307-312. http://dx.doi.org/10.1016/j.ijfoodmicro.2006.11.007

[33] Fayol-Messaoudi, D., Berger, C.N., Coconneir-Polter, M.H., Levin, V. and Servin, A.L. (2005) pH-, Lactic Acid- and Non-Lactic Acid-Dependent Activities of Probiotic Lactobacilli against Salmonella enterica Serovar Typhimurium. Applied Environmental Microbiology, 71, 6008-6013. http://dx.doi.org/10.1128/AEM.71.10.6008-6013.2005 